\title{
СТРУКТУРА ГОТОВНОСТІ МАЙБУТНІХ ВЧИТЕЛІВ-ЛОГОПЕДІВ ДО ЗАСТОСУВАННЯ АДАПТОВАНИХ ФІЗИЧНИХ ВПРАВ У ПРОФЕСІЙНІЙ ДІЯЛЬНОСТІ
}

\author{
Горшкова Г. В. \\ аспірант кафедри фізичної культури і спорту \\ Запорізький національний університет \\ вул. Жуковського, 66, Запоріжжя, Украӥна \\ orcid.org/0000-0002-2666-7925 \\ verona06@i.ua
}

\author{
Ключові слова: \\ адаптовані фізичні вправи, \\ готовність до професійної \\ діяльності, майбутні вчителі- \\ логопеди, компоненти \\ готовності, професійна \\ діяльність, структура \\ готовності.
}

Статтюприсвяченодослідженнюструктуриготовностімайбутніх вчителівлогопедів до застосування адаптованих фізичних вправ у професійній діяльності. Автором надано різні погляди вчених на тлумачення понять «готовність», «готовність до професійної діяльності», «готовність до педагогічної діяльності», «готовність спеціального (корекційного) педагога до професійної діяльності». У статті диференційовано поняття «професійна готовність», «професійна придатність», «готовність до професійної діяльності».

Автором зроблено висновок, що готовність майбутніх вчителівлогопедів до застосування адаптованих фізичних вправ $\epsilon$ складником їх професійної компетентності і трактується як інтегроване утворення, яке спирається на використання пристосованих фізичних вправ, що надає змогу організувати корекційно-розвиткову роботу 3 дітьми 3 порушеннями мовлення, спрямовану на ефективне їх подолання (або покращення стану мовлення), закріплення та стабілізацію результатів корекційно-розвиткової роботи у подальшому житті дитини та виступає передумовою ефективної професійної діяльності майбутнього вчителялогопеда після закінчення ЗВО.

Також висвітлено сім видів готовності: психологічну, суто професійну, комунікативну, особистісну, інноваційну, кар'єрну, психофізичну, що 3 різних сторін висвітлюють готовність до професійної діяльності майбутніх вчителів-логопедів. Запропоновано чотири компоненти готовності майбутніх вчителів-логопедів до застосування адаптованих фізичних вправ у професійній діяльності. Одним 3 тлумачень мотиваційного компоненту виступає потреба успішно виконати поставлене завдання, інтерес до діяльності. Когнітивний компонент автор представляє як оволодіння майбутнім вчителем-логопедом способами та прийомами, комплексом знань, умінь і навичок щодо розв'язування корекційнорозвиткових завдань, швидкого й адекватного орієнтування у численних і різнорідних ситуаціях професійного спілкування. Діяльнісний компонент передбачає інформаційно-технологічний складник, навчання рухових дій, відображає сформований комплекс певних умінь, навичок. Особистісний компонент характеризує почуття відповідальності, впевненості в успіху; управління собою, мобілізацію сил, зосередження на поставленому завданні, подолання сумнівів, страхів. 


\title{
STRUCTURE OF THE READINESS OF FUTURE SPEECH THERAPISTS TO APPLY ADAPTED PHYSICAL EXERCISES IN PROFESSIONAL ACTIVITY
}

\author{
Gorshkova G. V. \\ Postgraduate Student at the Department of Physical Culture and Sports \\ Zaporizhzhia National University \\ Zhukovskoho str., 66, Zaporizhzhia, Ukraine \\ orcid.org/0000-0002-2666-7925 \\ verona06@i.ua
}

\section{Key words:}

adapted physical exercises, readiness for professional activity, future speech therapists, and components of readiness, professional activity, and readiness structure.

\begin{abstract}
The article is devoted to the study of the structure of readiness of future teachers-speech therapists to apply adapted physical exercises in professional activities. The author provides different views of scientists on the interpretation of the concepts "readiness", "readiness for professional activity", "readiness for pedagogical activity", "readiness of a special (correctional) teacher for professional activity". The article differentiates the concepts of "professional readiness", "professional suitability", "readiness for professional activity".

The author concludes that the readiness of future speech therapists to use adapted physical exercises is part of their professional competence, is interpreting as an integrated education based on the use of adapted physical exercises, which allows organizing correctional and developmental work with children with speech disorders. Their effective overcoming (or improvement of speech), consolidation and stabilization of the results of correctional and developmental work in the further life of the child and is a prerequisite for effective professional activity of the future teacher-speech therapist after graduation. There are also seven types of readiness: psychological, purely professional, communicative, personal, innovative, career, psychophysical, which from different angles highlight the readiness for professional activities of future speech therapists. Four components of readiness of future teachersspeech therapists to apply adapted physical exercises in professional activity are offering. One of the explanations of the motivational component is the need to successfully completing the task, interest in the activity.

The author presents the cognitive component as the mastery of the future teacher-speech therapist methods and techniques, a set of knowledge, skills and abilities to solve correctional and developmental tasks, rapid and adequate orientation in numerous and diverse situations of professional communication. The activity component provides an information-technological component, training in motor actions, reflect the formed complex of certain abilities, skills. The personal component characterizes the sense of responsibility, confidence in success; self-management, mobilization of forces, focusing on the task, overcoming doubts, fears.
\end{abstract}

Постановка проблеми. Сучасна освітня система України повинна забезпечувати якісну професійну підготовку фахівців. Саме тому актуальності набувають питання, пов'язані з пошуком шляхів удосконалення освітнього процесу закладів вищої освіти для підвищення рівня фахової підготовки майбутніх вчителів-логопедів. Важливим засобом цього $є$ готовність майбутніх вчителів-логопедів до професійної діяльності.

Аналіз останніх досліджень і публікацій. Структурі готовності людини до професійної діяльності у сучасній науці приділяється особлива увага, оскільки іiі формування складає сутність професійного навчання та $є$ головним критерієм його якості.

Проблемою займалися та досліджували з різних методологічних позицій такі відомі вчені, як В.Г. Кремень, В.П. Андрющенко, І.А. Зязюн, Н.Г. Ничкало, С.О. Сисоєва, В.О. Сластенін, О.О. Бодальов, О.Ф. Бондаренко, Л. Е. Орбан-Лембрик, К.К. Платонов, Д.М. Узнадзе, Е.А. Фарапонова, В.С. Горгома, М.І. Д’яченко, В.В. Зарицька, Л.А. Кандибович, В.Г. Панок, Н.І. Пов'якель, О.В. Лапа, В.Й. Бочалюк, С.П. Миронова, 
Х.Я. Сайко, Р.В. Клопов, Л.В. Безкоровайна, А.М. Кух, Л.П. Сущенко тощо.

Однак варто констатувати, що, попри великий науковий інтерес і значні здобутки науковців 3 вивчення структури готовності до професійної діяльності, структуру готовності майбутніх вчителів-логопедів до застосування адаптованих фізичних вправ у професійній діяльності розглянуто недостатньо.

Мета статті полягає в дослідженні структури готовності майбутніх вчителів-логопедів до застосування адаптованих фізичних вправ у професійній діяльності.

Виклад основного матеріалу. Для з'ясування проблеми у нашому дослідженні вважаємо необхідним розглянути поняття «готовність», «готовність до професійної діяльності», «готовність до педагогічної діяльності», «готовність спеціального (корекційного) педагога до професійної діяльності».

Здійснивши аналіз наукових робіт вчених В.О. Моляко, К.К. Платонова, Х.Я. Сайко, С.Д. Максименко, К.С. Максименко, М.В. Папуча тощо, ми дійшли висновку, що поняття «готовність» визнається передусім як утворення, що пов'язано з особистістю, станом психічних процесів, умовами зростання, навчання, виховання i розвитку людини.

Готовність до професійної діяльності, за К.К. Платоновим, - результат трудового виховання, професійного навчання, психічної підготовки [1], за В. О. Сластьоніним, - професійна компетентність [2], яку держава законодавчо визначила як здатність особи у межах визначених за посадою повноважень застосовувати спеціальні знання, уміння та навички, виявляти від- повідні моральні та ділові якості для належного виконання встановлених завдань і обов'язків, навчання, професійного та особистісного розвитку [3]. В.Й. Бочелюк пропонує такі кроки готовності до професійної діяльності: 1) усвідомлення потреби у формуванні професійної компетентності, яке відбувається завдяки появі професійних запитань, завдань, які потребують вдосконалення діяльністю; 2) орієнтація майбутнього вчителя-логопеда на професійну і творчу реалізацію дозволяє йому поглибити усвідомлення актуальності і значущості власної професійної діяльності [4].

У літературних джерелах часто зустрічається ототожнене вживання понять «професійна готовність», «професійна придатність» і «готовність до професійної діяльності». Коротка характеристика понять наведена у таблиці 1. За твердженням вчених, категорія «професійна готовність» $\epsilon$ більш об'ємною, а категорія «готовність до професійної діяльності» $є$ підпорядкованою до неї [4], а правильність вибору професії з урахуванням професійної придатності визначається за двома критеріями: 1) ефективність праці, 2) внутрішня задоволеність своєю роботою і $\dddot{11}$ результатами. Професійну придатність, на нашу думку, можна визначити, по-перше, перед вступними іспитами, коли складають певні тести, які виявляють професійну придатність абітурієнта до професії взагалі (наприклад, у Казахстані до вступних іспитів до педагогічних університетів перевіряють абітурієнтів на професійну придатність), по-друге, безпосередньо під час трудової діяльності на робочому місці (коли людина відчуває свої реальні можливості).

Ми вважаємо, що зазначені поняття доповнюють одне одного, є частинами одного цілісного

Таблиця 1

Порівняльна таблиця понять «професійна придатність», «професійна готовність», «готовність до професійної діяльності»

\begin{tabular}{|c|c|c|}
\hline Професійна готовність & Професійна придатність & $\begin{array}{c}\text { Готовність } \\
\text { до професійної діяльності }\end{array}$ \\
\hline Особистісна якість & $\begin{array}{l}\text { Сукупність психологічних і психо- } \\
\text { фізичних властивостей: оволодін- } \\
\text { ня професією та ступінь задоволе- } \\
\text { ності від праці }\end{array}$ & $\begin{array}{l}\text { Особистісне утворення, професій- } \\
\text { на компетентність }\end{array}$ \\
\hline \multirow[t]{2}{*}{$\begin{array}{l}\text { Види: } \\
\text { - попередня (завчасна, потенційна) } \\
\text { - безпосередня(миттєва, ситуаційна) }\end{array}$} & $\begin{array}{l}\text { Види: } \\
\text { - абсолютна } \\
- \text { відносна }\end{array}$ & $\begin{array}{l}\text { Складники: } \\
\text { - психологічна } \\
\text { - суто професійна } \\
\text { - комунікативна } \\
\text { - особистісна } \\
\text { - інноваційна } \\
\text { - кар'єрна } \\
\text { - психофізична } \\
\end{array}$ \\
\hline & $\begin{array}{l}\text { Критерії оцінювання: } \\
\text { - медичний } \\
\text { - освітній } \\
\text { - психологічний }\end{array}$ & \\
\hline
\end{tabular}


процесу. Однак, на нашу думку, якщо «професійна готовність» і «готовність до професійної діяльності» $є$ близькими поняттями, такими, що належать до підготовки фахівців у ЗВО, то «професійна придатність» $є$ поняттям, більше наближеним до трудової діяльності.

Майбутній вчитель-логопед - це педагог. Виправданим часом $є$ визначення К.М. Дурай-Новакової щодо професійної готовності студентів до педагогічної діяльності як цілісного вираження всіх підструктур особистості, зорієнтованих на повне й успішне виконання різноманітних функцій учителя, складного структурного утворення, центральним ядром якого $€$ позитивні настанови, мотиви й освоєні цінності педагогічної професії, до якого входять професійно важливі риси характеру, здібності, сукупність професійно-педагогічних знань, навичок, умінь, певний досвід їхнього застосування на практиці [5]. Науковці Л.А. Гончаренко, В.О. Сластьонін готовність до педагогічної діяльності надають як систему: 1) психологічна готовність як потреба у педагогічній діяльності; 2) теоретична підготовленість до педагогічної діяльності; 3) практична готовність до професії вчителя; 4) ідейно-політична підготовка, світогляд та загальна культура вчителя; 5) педагогічні здібності; 6) професійно-педагогічна спрямованість особистості вчителя $[2 ; 6]$.

На наш погляд, готовність до педагогічної діяльності потребує від майбутніх педагогів високих моральних якостей, певних здібностей, вміння спілкуватись із різними категоріями людей у різних обставинах та вміння миттєво приймати правильні рішення.

3'ясуємо поняття «готовність майбутнього вчителя-логопеда до професійної діяльності». Науковець О.І. Проскурняк зазначає, що готовність корекційного педагога до професійної діяльності виявляється насамперед у його здатності до організації, виконання й регулювання педагогічної діяльності; зумовлюється багатьма факторами, найважливішим 3 яких $є$ наявність особистісних властивостей, покликання, що $е$ сукупністю знань та вмінь, емоцій і волі, уподобань та інтересів, які безпосередньо включені у освітній процес, і виражаються через вплив на особистість учня з метою формування характерологічних властивостей та важливих умінь i навичок [7]. Готовність корекційного педагога до професійної діяльності, на думку Х.Я. Сайко, виявляється насамперед у його здатності до організації, виконання і регулювання педагогічної діяльності; зумовлюється багатьма факторами, найважливішим 3 яких $\epsilon$ наявність особистісних властивостей, покликання, що $є$ сукупністю знань та вмінь, емоцій і волі, схильностей та інтересів, які безпосередньо включені в навчаль- но-педагогічний процес, i виражаються через вплив на особистість учня з метою формування характерологічних властивостей та важливих вмінь і навичок. [8]. О.В. Мартинчук готовність спеціального педагога до інклюзивного навчання позначає як системну інтегровану якість фахівця, яка визначає спрямованість, поведінкові стратегії і методи професійно-педагогічної діяльності в умовах інклюзивного освітнього середовища [9].

Отже, на нашу думку, готовність майбутнього вчителя-логопеда до професійної діяльності полягає у засвоєнні повного складу спеціальних знань (з навчальних дисциплін під час навчання у ЗВО) та соціальних відносин, у сформованості й зрілості професійно значущих і громадських якостей особистості; на додачу до тлумачення «готовності до професійної діяльності» і «готовності до педагогічної діяльності» містить особливий стан особистості, схильність до емпатії, до співчуття стосовно дітей з особливими освітніми потребами.

Здійснивши аналіз думок науковців М.І. Д'яченко, Л.А. Кандибович, В.О. Сластьоніна, О.А. Черепєхіної, В.Й. Бочелюка, С.В. Альохіна, М.Н. Алексіїва, І.М. Кобзар, С.Д. Максименко, Х.Я. Сайко, К.І. Бондарєва, О.Г. Козлова, I.M. Дичківської, О.І. Огієнко, Т.Г. Калюжної, Д.О. Закатнова, О.К. Маркова, Є.О. Могільовкіна, ми дійшли висновку, що можна виділити такі види готовності, що 3 різних сторін висвітлюють готовність до професійної діяльності майбутніх вчителів-логопедів (рис. 1), а саме:

- психологічна готовність: 1) ступінь підготовленості та налаштованості психіки, духовних сил спеціаліста на рішення професійних задач, виконання своїх функціональних обов'язків; 2) комплекс мотивів, знань, умінь та навичок, особистісних якостей, які забезпечують успішну взаємодію майбутнього вчителя-логопеда 3 учасниками професійної діяльності й ефективність діяльності загалом; 3) виділяють: а) завчасну, б) загальну (тривалу), в) ситуащійну психологічну готовність;

- суто професійна готовність: інформаційна готовність, володіння педагогічними технологіями, знання основ психології та корекційної педагогіки, знаннями про загальні та індивідуальні особливості дітей з різними порушеннями розвитку, моделювання занять та використання варіативності в освітньому процесі, неперервне професійне навчання;

- комунікативна готовність: 1) наявність вмінь і навичок конструктивної та ефективної взаємодії у професійному середовищі, підтримка і розвиток такої взаємодії; 2) достатній рівень мовленнєвої культури, яка виступає показником розвитку професійного мислення; 3) розвиток почуття емпатії, доброзичливості, товариськості, почуття дружби, колективізму; 4) ерудованість; 


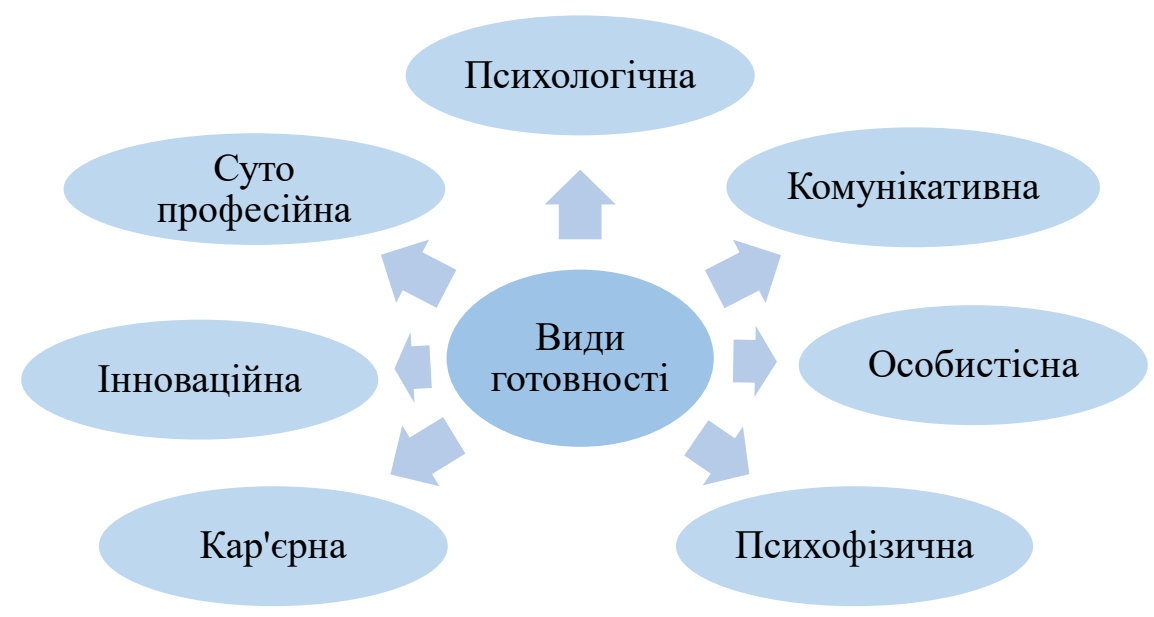

\section{Рис. 1. Види готовності, що з різних сторін висвітлюють готовність до професійної діяльності майбутнього вчителя-логопеда}

5) цілеспрямованість вияву потенціалу особистості до обміну різного роду інформації вербальними та невербальними засобами;

- особистісна готовність виражається у певному ставленні до діяльності, ситуації, інших людей, самого себе; виступає необхідною умовою успішної професійної самореалізації та психологічної діяльності; розуміється як комплексне психологічне утворення, поєднання функціональних, операційних та особистісних компонентів через наявність мотивів діяльності, пізнавального ставлення до зовнішнього світу, достатнього емоційного і вольового розвитку психіки;

- інновачійна готовність: 1) здатність нетрадиційно вирішувати освітні проблеми; 2) необхідність творчого розвитку шляхом впровадження інноваційних технологій в освітній процес; 3) особливий стан, який передбачає наявність мотиваційно-ціннісного ставлення до професійної діяльності, володіння ефективними способами і засобами досягнення педагогічних цілей, здатності до творчості та рефлексії; 4) інтегративна якість особистості педагога, що спрямована на створення, запровадження та розповсюдження освітніх новацій та формування інноваційної позиції педагога;

- кар'єрна готовність: 1) готовність і здатність до професійного та особистісного самоствердження і відповідна активність у цьому напряму; 2) прагнення реалізовувати себе під час вирішення професійних завдань та у взаємовідносинах із співробітниками, колегами по роботі; 3) успішність самоствердження, яка залежить від бажання i прагнення домогтися успіху, від установки на успіх, від готовності до успіху; 4) кар'єрні орієнтації, які виникають у процесі навчання у ЗВО і можуть залишатися стабільними протягом тривалого часу; 5) планування кар'єри як процес зістав- лення потенційних можливостей, здібностей i цілей з вимогами організації, стратегією і планами розвитку, що виражається у складанні програми професійного і посадового зростання;

- психофізична готовність: 1) ступінь відповідності змісту і стану психіки і фізичного здоров'я, якості діяльності, що виконується; б) наявність відповідного рівня фізичного здоров'я, сформованості і розвиненості необхідних для успішної професійної діяльності фізичних якостей, наявність відповідного рівня фізичної культури особистості, оскільки будь-яка професійна діяльність вбачає різні рівні втрати людиною фізичних сил, фізичної енергії, пов'язані з витратами психічної і фізичної енергетики.

Проаналізувавши думки вчених, можна зазначити, що формування готовності майбутніх вчителів-логопедів до застосування адаптованих фізичних вправ у професійній діяльності є метою та результатом тривалого процесу підготовки фахівця. Здійснивши аналіз наукової літератури, нами не виявлено чіткого та загальноприйнятого визначення поняття «готовність до професійної діяльності», попри довгу історію вивчення цієї проблеми.

Отже, можна дійти висновку, що готовність майбутніх вчителів-логопедів до застосування адаптованих фізичних вправ є складником їх професійної компетентності, трактується як інтегроване утворення, яке спирається на використання пристосованих (з урахуванням віку дитини, етіології та тяжкості порушення) фізичних вправ, що надає змогу організувати корекційно-розвиткову роботу з дітьми різного віку з порушеннями мовлення, спрямовану на ефективне їх подолання (або покращення стану мовлення), закріплення та стабілізації результатів корекційно-розвиткової роботи у подальшому житті дитини; висту- 
пає передумовою ефективної діяльності майбутніх вчителів-логопедів після закінчення 3ВО; допомагає успішно виконувати свої професійні обов'язки, реалізувати знання, уміння і навички та у майбутньому набувати досвіду у професійній діяльності.

Спираючись на теоретичний аналіз думок науковців М.І. Дьяченко, Л.О. Кандибович, В.О. Сластьоніна, А.О. Деркач, Л.Е. Орбан, О.В. Мартинчук, ми дійшли висновку, що готовність майбутніх вчителів-логопедів до застосування адаптованих фізичних вправ у професійній діяльності містить такі компоненти (рис. 2):

- мотиваційний - потреба успішно виконати поставлене завдання, інтерес до діяльності; прагнення: 1) досягти успіху і показати себе 3 кращого боку, 2) оволодіння системою знань, умінь, навичок щодо здійснення корекційно-розвиткової роботи; 3) розроблення та впровадження інноваційних форм з огляду на впровадження інклюзивного навчання для дітей із особливими освітніми потребами (порушеннями мовлення) із застосуванням адаптованих фізичних вправ; наявність потреб, мотивів, прагнень до успішної діяльності, прояв відповідальності за розв'язання педагогічних задач, почуття обов'язку;

- когнітивний-розуміння обов'язків, завдань, оцінки їх значимості, знання засобів досягнення мети, уявлення про ймовірні зміни ситуації та наявність системи знань із основ корекційно-розвиткової роботи, сучасних моделей надання спе- ціальних освітніх послуг для дітей із особливими освітніми потребами (порушеннями мовлення) на основі інтегративного та інклюзивного підходів із застосування адаптованих фізичних вправ; оволодіння майбутнім вчителем-логопедом способами та прийомами, комплексом знань, умінь і навичок щодо розв'язування корекційно-розвиткових завдань, швидкого й адекватного орієнтування у численних і різнорідних ситуаціях професійного спілкування;

- діяльнісний - передбачає інформаційно-технологічний складник, навчання рухових дій, відображає сформований комплекс умінь, навичок, здатності до виконання корекційно-розвиткової роботи 3 дітьми 3 особливими освітніми потребами (порушеннями мовлення) із застосуванням адаптованих фізичних вправ;

- особистісний - характеризує почуття відповідальності, впевненості в успіху; управління собою, мобілізацію сил, зосередження на поставленому завданні, подолання сумнівів, страхів; рівень розвитку і задоволеності фізичної, духовної, психічної, соціальної сфер життя особистості; наявність інтегративних властивостей професійного, творчого мислення і рефлексії, чіткого розуміння професійних завдань із корекційно-розвиткової роботи 3 дітьми $з$ особливими освітніми потребами (порушеннями мовлення), способів їх вирішення на основі сучасних інноваційних ідей 3 огляду на впровадження інклюзивної освіти із застосуванням адаптованих фізичних вправ.

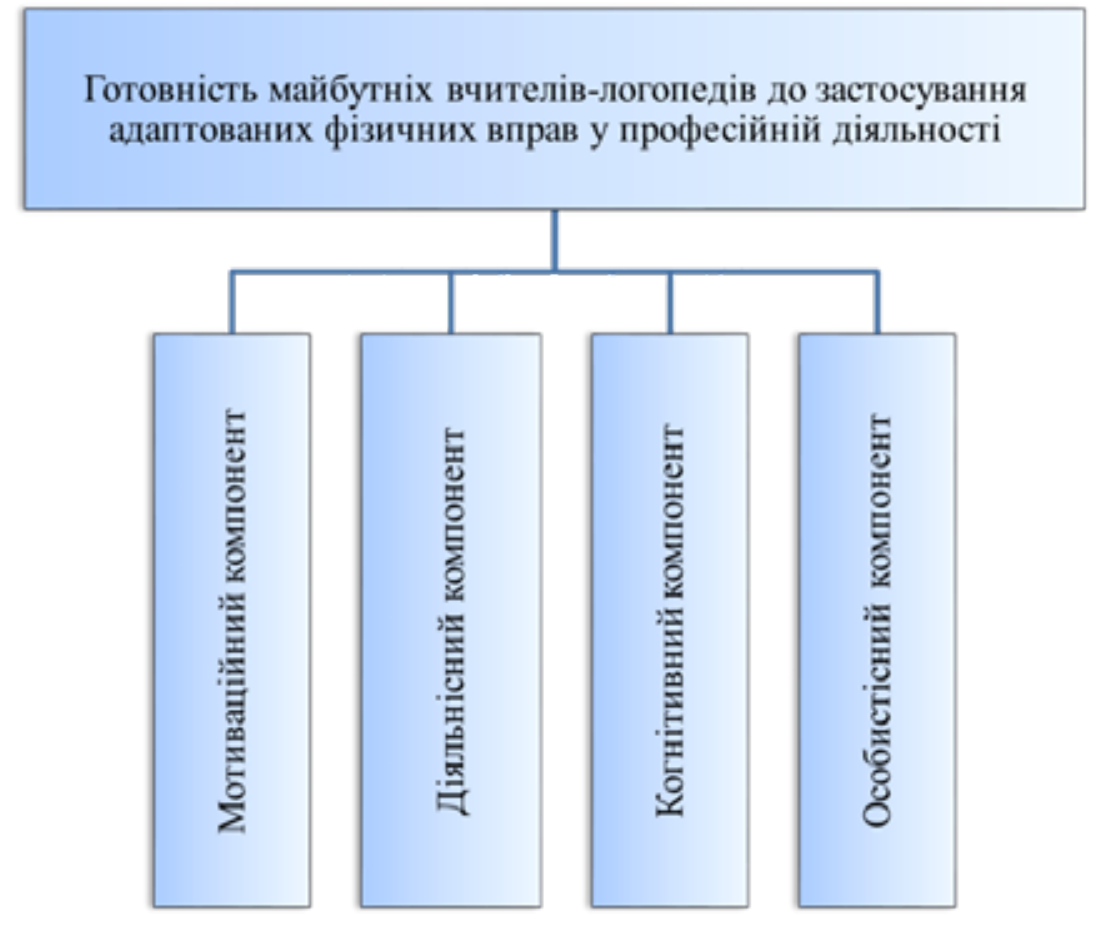

Рис. 2. Компоненти готовності майбутніх вчителів-логопедів до застосування адаптованих фізичних вправ у професійній діяльності 
Кожен із цих компонентів дає змогу визначити критерії та показники, за якими можливо оцінити готовність майбутнього вчителя-логопеда до застосування адаптованих фізичних вправ у професійній діяльності.

Висновки. Отже, можна дійти висновку, що проблема структури готовності майбутніх вчителів-логопедів до застосування адаптованих фізичних вправ у професійній діяльності $\epsilon$ актуальною і недостатньо вивченою. Струк- тура готовності майбутніх вчителів-логопедів до застосування адаптованих фізичних вправ у професійній діяльності містить мотиваційний, когнітивний, діяльнісний, особистісний компоненти.

Проблема потребує подальшого дослідження, одним 3 напрямів якого є розробка критеріїв сформованості готовності майбутніх вчителів-логопедів до застосування адаптованих фізичних вправ у професійній діяльності.

\section{Література}

1. Платонов К. К. Структура и развитие личности. Москва : Наука, 1986. 255 с.

2. Педагогика : учебное пособие для студентов высших педагогических учебных заведений / под ред. В.А. Сластенина. Москва : Академия, 2002. 566 с.

3. Закон України «Про державну службу». P.I, ст. 2, п.1. URL: https://zakon.rada.gov.ua/laws/show/889-19 (дата звернення : 23.02.2020).

4. Бочелюк В.Й. Особливості готовності майбутніх психологів до роботи з попередження віктимної поведінки підлітків. Вісник Харківського національного педагогічного університету імені Г. С. Сковороди. Психологія. 2014. Вип. 48. С. 12-22.

5. Дурай-Новакова К.М. Формирование профессиональной готовности к педагогической деятельности. Москва : Политиздат, 1983. 356 с.

6. Гончаренко Л.А. Полікультурна освіченість педагога: теорія і практика / за ред. В.В. Кузьменка. Херсон : РІПО, 2009. 136c.

7. Проскурняк О.I. До проблеми підготовки корекційних педагогів до професійної освіти. Сумський державний педагогічний університет імені А. С. Макаренко. Педагогічні науки: теорія, історія, інновачійні технології. 2016, № 4 (58). С. 408-415.

8. Сайко Х.Я. Особистісна готовність корекційного педагога до виховання дітей з аутизмом : навчальний посібник. Львів : Тріада Плюс, 2017. 248 с.

9. Мартинчук О.В. Концепція підготовки майбутніх фахівців у галузі спеціальної освіти до професійної діяльності в освітньому середовищі. Збірник наукових праць Хмельницького інституту соиіальних технологій Університету «Україна». 2018. № (1) 15. С. 49-53.

\section{References}

1. Platonov K. K. (1988) Struktura i razvitiye lichnosti [Structure and development of personality]. Moscow : Nauka, 1986. $255 \mathrm{p}$.

2. Pedagogika (2002) : uchebnoye posobiye dlya studentov vysshikh pedagogicheskikh uchebnykh zavedeniy [Pedagogy: a textbook for students of higher pedagogical educational institutions / ed. V.A. Slastenin]. Moscow : Academy. $566 \mathrm{p}$.

3. Zakon Ukrayiny "Pro derzhavnu sluzhbu" [Law of Ukraine "On Civil Service"]. RI, Art. 2, p. 1. URL: https://zakon.rada.gov.ua/laws/show/889-19.

4. Bochelyuk V. Y. (2014) Osoblyvosti hotovnosti maybutnikh psykholohiv do roboty z poperedzhennya viktymnoyi povedinky pidlitkiv [Features of the readiness of future psychologists to work to prevent victim behavior of adolescents]. Bulletin of GS Skovoroda Kharkiv National Pedagogical University. Psychology. Vol. 48. P. 12-22.

5. Durai-Novakova K.M. (1983) Formirovaniye professionalnoy gotovnosti k pedagogicheskoy deyatel'nosti [Formation of professional readiness for pedagogical activity]. Moscow : Politizdat. $356 \mathrm{p}$.

6. Honcharenko L.A. (2009) Polikulturna osvichenist' pedahoha: teoriya i praktyka [Multicultural education of the teacher: theory and practice / ed. V. V. Kuzmenko]. Kherson : RIPO. 136 p.

7. Proskurnyak O.I. (2016) Do problemy pidhotovky korektsiynykh pedahohiv do profesiynoyi osvity [On the problem of training correctional teachers for professional education. Sumy State Pedagogical University named after AS Makarenko. Pedagogical sciences: theory, history, innovative technologies. Vol. 4 (58). P. 408-415.

8. Saiko H.Ya. (2017) Osobystisna hotovnist' korektsiynoho pedahoha do vykhovannya ditey z autyzmom: navchal'nyy posibnyk [Personal readiness of a correctional teacher to educate children with autism: a textbook]. Lviv : Triad Plus. 248 p.

9. Martinchuk O.V. (2018) Kontseptsiya pidhotovky maybutnikh fakhivtsiv u haluzi spetsial'noyi osvity do profesiynoyi diyal'nosti v osvitn'omu osvitn'omu seredovyshchi [The concept of training future professionals in the field of special education for professional activities in the educational environment]. Collection of scientific works of the Khmelnytsky Institute of Social Technologies of the University Ukraine. Vol. (1) 15. P. 49-53. 